\title{
Pengaruh Model Pembelajaran Aptitude Treatment Interaction Terhadap Kemampuan Komunikasi Matematika
}

\author{
Indah Lestari * \\ Universitas Indraprasta PGRI Kota Jakarta Selatan, DKI Jakarta 12530, Indonesia \\ Pengiriman: 31 Juli 2018; Diterima: 29 September 2018; Publikasi: 30 September 2018 \\ DOI: https://doi.org/10.31629/jg.v3i2.478
}

\begin{abstract}
Abstrak
Penelitian ini bertujuan untuk mengetahui perbedaan kemampuan komunikasi matematika peserta didik yang memperoleh pembelajaran Aptitude Treatment Interaction dan ekspositori. Penelitian ini dilakukan pada mahasiswa program studi Pendidikan Matematika Universitas Indraprasta PGRI. Metode penelitian yang digunakan adalah eksperimen dengan jumlah sampel sebanyak 50 responden. Variabel bebas dalam penelitian ini adalah model pembelajaran yaitu Aptitude Treatment Interaction dan ekspositori, sedangkan variabel terikat adalah kemampuan komunikasi Matematika. Teknik pengolahan data dengan menggunakan uji beda 2 rata-rata. Hasil penelitian menunjukkan bahwa penerapan model pembelajaran Aptitude Treatment Interaction mempengaruhi kemampuan komunikasi matematika.
\end{abstract}

Kata kunci: Aptitude Treatment Interaction; komunikasi; matematika

\begin{abstract}
This research aims to know the differences of mathematical communication ability of learners who acquire Aptitude Treatment Interaction and exspository learning model. This research was conducted on student of Mathematics Education Study Programme at University of Indraprasta PGRI. The research method used was experiment with sample number of as many as 50 respondents. Independent variables in this study were models of learning, namely Aptitude Treatment Interaction and expository, while dependent variable is the ability of mathematical communication. Data processing techniques used was comparing the mean of two population. The results showed that the application of Aptitude Treatment Interaction learning model affects the ability of mathematical communication.
\end{abstract}

Keywords: Aptitude Treatment Interaction; communication; mathematics

\section{Pendahuluan}

Matematika dalam dunia pendidikan menjadi salah satu bidang studi yang sangat penting. Matematika sebagai ilmu dasar yang diajarkan di berbagai level pendidikan diharapkan mampu mengembangkan kemampuan berpikir logis, analitis, sistematis, komunikatif, kritis dan kreatif. Kemampuan tersebut sangat dibutuhkan agar dapat menghadapi perubahan keadaan di dalam kehidupan yang terus berkembang. Mengingat begitu pentingnya matematika sudah selayaknya 


\section{JURNAL GANTANG. September 2018; III(2): 153 - 160 \\ p-ISSN. 2503-0671 \\ e-ISSN. 2548-5547}

peserta didik menguasai kemampuankemampuan yang terdapat dalam matematika.

Kemampuan komunikasi matematika belum sepenuhnya dikembangkan dalam proses pembelajaran sehingga kemampuan komunikasi matematika masih rendah. Proses pembelajaran di kelas lebih cenderung melihat hasil yang benar tanpa memperhatikan proses memperoleh hasil tersebut. Pada mahasiswa Program Studi Pendidikan Matematika di Universitas Indraprasta, kemampuan mahasiswa dalam menyelesaikan soal yang mengharuskan mereka menganalisis atau menghubungkan situasi yang diberikan ke dalam bentuk diagram atau bentuk matematika masih rendah. Misalnya pada mata kuliah Kalkulus, Metode Numerik, Program linier, Analisa Real maupun Statistika Matematika. Nilai akhir dari mata kuliah ini masih belum memuaskan.

Kemampuan komunikasi matematika adalah kemampuan dalam menghubungkan benda nyata, gambar, dan diagram ke dalam ide matematika; menjelaskan ide, situasi, dan relasi matematik baik secara lisan maupun tulisan dalam bentuk gambar atau grafik; menjelaskan serta membuat pertanyaan tentang matematika yang dipelajari dari suatu situasi yang diberikan (Elida, 2012). Kemampuan komunikasi matematika merupakan kemampuan mengkomunikasikan gagasan atau ide-ide matematika ke dalam simbol, tabel, grafik atau diagram maupun sebaliknya untuk memperjelas keadaan atau masalah serta pemecahannya (Firdaus \& Chyntia, 2016). Artinya komunikasi matematika terjadi ketika mahasiswa mampu menyampaikan apa yang diketahuinya serta mampu memecahkan permasalahan mengenai matematika. Komunikasi matematika tidak hanya tentang pengungkapan ide matematika secara lisan namun juga dalam bentuk tulisan.

Kemampuan komunikasi matematis dapat diartikan sebagai suatu kemampuan dalam menyampaikan sesuatu yang diketahuinya melalui peristiwa dialog atau saling hubungan yang terjadi dilingkungan belajar, dimana terjadi pengalihan pesan.
Pesan yang dialihkan berisi tentang materi matematika yang dipelajari, misalnya berupa konsep, rumus, atau strategi penyelesaian suatu masalah (Nofrianto, Maryuni, \& Amri, 2017).

Rendahnya komunikasi matematika dipengaruhi banyak faktor. Faktor dari dalam diri mahasiswa misalnya. Mahasiswa menganggap mata kuliah tertentu adalah mata kuliah sulit. Misalnya dalam mata kuliah Metode Numerik, mahasiswa harus memiliki kemampuan komunikasi yang cukup baik agar dapat menyelesaikan setiap soal Metode Numerik yang diberikan. Kesulitan ini dikarenakan banyaknya simbol dan rumus yang menambah kesulitan dalam mengerjakan soal. Selain faktor dari dalam, faktor dari luar juga mempengaruhi rendahnya kemampuan komunikasi matematika. Model pembelajaran yang monoton serta sistem pembelajaran yang berpusat pada dosen menyebabkan mahasiswa tidak terlibat aktif dalam proses pembelajaran. Hal tersebut menjadikan mahasiswa kurang berpartisipasi dalam proses pembelajaran. Tidak terdapatnya pembelajaran dua arah antara mahasiswa dan dosen yang menyebabkan proses pembelajaran tidak berjalan efektif. Penyajian materi matematika biasanya membuat pebelajar kurang merasa tertarik untuk mengikuti pembelajaran matematika (Irawan \& Febriyanti, 2016).

Pembelajaran yang efektif mampu membantu mahasiswa di kelas menguasai kompetensi minimal yang telah di tetapkan, dengan pembelajaran tersebut mahasiswa mendapatkan pembelajaran yang sesuai dengan kemampuan masing-masing. Fenomena ini, baik yang menyangkut rendahnya kualitas kemampuan komunikasi matematika mahasiswa maupun pembelajaran yang belum dapat mengapresiasikan dan mengakomodasi perbedaan individual (aptitude), merupakan suatu tantangan yang harus dihadapi. Maka perlu diterapkan model pembelajaran Aptitude Treatment Interaction (ATI).

ATI is a learning model that can serve 
individual differences of students that are to adjust the treatment or learning methods with the ability of students (Syawal; Patahuddin; Alimuddin, 2017). Aptitude Treatment Interaction (ATI) merupakan sebuah model pembelajaran yang berisikan sejumlah strategi pembelajaran yang efektif digunakan untuk siswa tertentu sesuai dengan karakteristik kemampuannya. Didasari oleh asumsi bahwa optimalisasi prestasi akademik/hasil belajar dapat dicapai melalui penyesuaian antara pembelajaran (treatment) dengan perbedaan kemampuan (aptitude) (Nuraini, Ainy, \& Suprapti, 2006).

ATI merupakan model pembelajaran yang berusaha terus menemukan perlakuan yang cocok dengan perbedaan kemampuan masingmasing mahasiswa. Dengan menggunakan model pembelajaran ATI, setiap mahasiswa akan mendapat perlakuan sesuai dengan karakteristik kemampuanya masing-masing. Dengan demikian, diharapkan pembelajaran akan lebih mudah

Pada awal pembelajaran, akan diberikan pretest untuk mengetahui kemampuan masingmasing mahasiswa. Selanjutnya akan dibagi kelompok sesuai dengan kemampuan dalam kategori rendah, sedang dan tinggi. Kelompok peserta didik dengan kategori rendah akan memperoleh pembelajaran dan perhatian lebih banyak dibandingkan peserta didik dengan kemampuan tinggi.

Penggunaan model ATI pada pembelajaran lebih ditekankan dalam kerja kelompok atau kerja sama antar teman sebaya, sehingga hasil belajar diharapkan dapat ditingkatkan (Saregar, Diani, \& Kholid, 2017). Mahasiswa dengan kemampuan komunikasi matematika tinggi dapat membantu teman yang memiliki kemampuan komunikasi sedang ataupun rendah. Hal ini diharapkan dapat membantu dalam meningkatkan kemampuan komunikasi matematika setiap mahasiswa.

Berdasarkan uraian diatas, peninjauan tentang pengaruh model pembelajaran ATI terhadap kemampuan komunikasi matematika perlu dikaji selanjutnya.

\section{Metode Penelitian}

Penelitian ini merupakan penelitian eksperimen dengan menerapkan model pembelajaran ATI dan model pembelajaran ekspositori. Penelitian ini menempatkan kemampuan komunikasi matematika sebagai variabel terikat $(\mathrm{Y})$ dan model pembelajaran sebagai variabel bebas $(\mathrm{X})$.

Jenis penelitian ini adalah kuasi eksperimen dengan pendekatan kuantitatif. Populasi dalam penelitian adalah mahasiswa semester 6 program studi Pendidikan Matematika Universitas Indraprasta PGRI. Penelitian dilakukan pada semester genap tahun ajaran 2017/2018. Teknik sampling yang digunakan adalah multi stage sampling sebanyak 2 tahap. Tahap pertama memilih kelas dimana dalam tahap ini dipilih dua kelas secara acak yaitu kelas R6G sebagai kelas kontrol dan kelas R6D sebagai kelas eksperimen. Selanjutnya tahap kedua memilih sampel penelitian (mahasiswa). Dari setiap kelas yang telah terpilih diambil secara acak sampel sebanyak 25 mahasiswa sehingga jumlah sampel sebanyak 50 responden.

Variabel dalam penelitian ini terdiri dari variabel terikat dan bebas. Variabel terikat yaitu kemampuan komunikasi matematika. Teknik pengumpulan data dengan menggunakan tes berbentuk uraian sebanyak 5 soal dengan indikator yaitu: (1) mengekspresikan ide matematika ke bentuk lainnya, (2) menginterpretasi dan mengevaluasi ide matematika ke dalam bentuk lainnya, dan (3) menyajikan informasi yang diberikan ke dalam bentuk tabel dan mengevaluasinya.

Variabel bebas yaitu model pembelajaran ATI yang diterapkan di kelas eksperimen dan model pembelajaran ekspositori yang diterapkan di kelas kontrol.

Data yang terkumpul diolah secara deskriptif menggunakan software SPSS 21 untuk mencari ukuran pemusatan data selanjutnya diuji normalitas dan homogenitasnya. Kemudian data dianalisis dengan teknik uji beda 2 rata-rata sampel bebas menggunakan uji-t. Hipotesis 
JURNAL GANTANG. September 2018; III(2): 153 - 160

p-ISSN. 2503-0671

e-ISSN. 2548-5547

dalam penelitian ini adalah:

Ho : Tidak terdapat pengaruh model pembelajaran ATI terhadap kemampuan komunikasi matematika

H1 : Terdapat pengaruh model pembelajaran ATI terhadap kemampuan komunikasi matematika.

Kriteria pengujiannya adalah terima Ho jika nilai sig. > 0,05.

\section{Hasil dan Pembahasan}

Penelitian ini dilakukan pada mahasiswa semester 6 program studi Pendidikan Matematika, Universitas Indraprasta pada mata kuliah metode numerik. Pada kelas eksperimen yaitu kelas R6D diterapkan model pembelajaran ATI sedangkan kelas kontrol yaitu kelas R6G diterapkan model pembelajaran ekspositori. Setelah proses pembelajaran selesai selanjutnya diberikan tes berbentuk uraian untuk mengukur kemampuan komunikasi matematika. Data deskriptif dari kemampuan komunikasi matematika dapat dilihat pada tabel 1 .

Tabel 1.

Data deskriptif kemampuan komunikasi matematika

\begin{tabular}{|c|c|c|c|}
\hline & $\mathrm{N}$ & Mean & $\begin{array}{c}\text { Std. } \\
\text { Deviation }\end{array}$ \\
\hline $\begin{array}{l}\text { Aptitude Treatment } \\
\text { Interaction }\end{array}$ & 25 & 77.44 & 6.917 \\
\hline Ekspositori & 25 & 63.60 & 8.888 \\
\hline \multirow[t]{2}{*}{ Total } & 50 & 70.52 & 10.535 \\
\hline & $\begin{array}{l}\text { Std. } \\
\text { Error }\end{array}$ & $\begin{array}{l}\text { Mini } \\
\text { mum }\end{array}$ & $\begin{array}{l}\text { Maxi } \\
\text { mum }\end{array}$ \\
\hline $\begin{array}{l}\text { Aptitude Treatment } \\
\text { Interaction }\end{array}$ & 1.383 & 64 & 92 \\
\hline Ekspositori & 1.778 & 48 & 80 \\
\hline Total & 1.490 & 48 & 92 \\
\hline
\end{tabular}

Berdasarkan tabel diatas terlihat nilai rata-rata data kemampuan komunikasi matematika pada kelas yang diajarkan dengan model API adalah sebesar 77,44 lebih tinggi dari kelas yang diajarkan model ekspositori yaitu sebesar 63,60. Nilai minimum dari kelompok eksperimen lebih tinggi dari kelas kontrol, begitupula dengan nilai maksimum kelas eksperimen yang juga lebih tinggi dari kelas kontrol. Hal ini dapat diartikan bahwa kemampuan komunikasi matematika yang diajarkan dengan model ATI lebih tinggi daripada kelas yang diajar dengan model ekspositori.

Sebelum data dianalisis, uji normalitas dan uji homogenitas data kemampuan komunikasi matematika pada setiap kelompok data dilakukan sebagai uji persyaratan analisis data. Uji normalitas tersaji pada tabel 2 . Berdasarkan tabel 2 terlihat bahwa sampel dari tiap kelompok data memiliki nilai Sig. > 0,05 maka dapat disimpulkan bahwa semua kelompok data kemampuan komunikasi matematika berdistribusi normal.

Tabel 2 .

Uji normalitas

\begin{tabular}{|c|c|c|c|c|}
\hline & \multirow{2}{*}{$\begin{array}{l}\text { Model } \\
\text { Pembelajaran }\end{array}$} & \multicolumn{3}{|c|}{$\begin{array}{c}\text { Kolmogorov- } \\
\text { Smirnov }^{\mathrm{a}}\end{array}$} \\
\hline & & Statistic & Df & Sig. \\
\hline \multirow{3}{*}{$\begin{array}{l}\text { Kemampuan } \\
\text { Komunikasi } \\
\text { matematika }\end{array}$} & Aptitude & 0.156 & 25 & 0.121 \\
\hline & $\begin{array}{l}\text { Treatment } \\
\text { Interaction }\end{array}$ & & & \\
\hline & Ekspositori & 0.170 & 25 & 0.061 \\
\hline
\end{tabular}

Pengujian homogenitas data kemampuan komunikasi matematika pada mahasiswa kelas eksperimen dan kontrol dapat dilihat pada tabel 3.

Tabel 3.

Uji homogenitas

Test of Homogenity of Variances

Kemampuan Komunikasi matematika

\begin{tabular}{c|c|c|c} 
Levene Statistic & $\mathrm{df} 1$ & $\mathrm{f} 2$ & Sig. \\
\hline 2.009 & 1 & 8 & 0.163 \\
\hline
\end{tabular}

Dari tabel 3 berdasarkan uji Levene Statistic diperoleh nilai Sig. 0,163>0,05, maka dapat disimpulkan bahwa data kemampuan komunikasi matematika memiliki varians yang sama atau homogen. Karena data memiliki distribusi normal dan homogen, maka dilakukan uji analisis yaitu uji beda dua rata-rata dengan uji-t, hasil analisis dapat dilihat pada tabel 4 . 
Tabel 4.

Uji analisis data

\begin{tabular}{|c|c|c|c|c|}
\hline & & $\mathrm{T}$ & df & $\begin{array}{l}\text { Sig. (2- } \\
\text { tailed) }\end{array}$ \\
\hline \multirow[t]{2}{*}{$\begin{array}{l}\text { Kemampuan } \\
\text { Komunikasi } \\
\text { matematika }\end{array}$} & $\begin{array}{l}\text { Equal } \\
\text { variances } \\
\text { assumed }\end{array}$ & 6.14 & 48 & 0.000 \\
\hline & $\begin{array}{l}\text { Equal } \\
\text { variances } \\
\text { not } \\
\text { assumed }\end{array}$ & 6.14 & 45.268 & 0.000 \\
\hline
\end{tabular}

Berdasarkan tabel 4 diperoleh nilai sig. sebesar $0,000<0,05$ maka disimpulkan $\mathrm{H}_{\mathrm{o}}$ ditolak yang artinya terdapat perbedaan nilai kemampuan komunikasi matematika mahasiswa yang diajar dengan model pembelajaran ATI dan model pembelajaran ekspositori. Hal ini didukung dari nilai rata-rata kemampuan komunikasi matematika yang diajar dengan model pembelajaran ATI lebih tinggi dari kelompok mahasiswa yang diajar dengan model pembelajaran ekspositori. Maka dapat disimpulkan terdapat pengaruh model pembelajaran ATI terhadap kemampuan komunikasi matematika.

Kemampuan komunikasi matematika berkaitan dengan bagaimana mahasiswa mampu memahami permasalahan dari soal yang sedang dipelajari, mahasiswa mampu mengkomunikasikan pertanyaan ke dalam bentuk simbol dan rumus yang diminta sesuai soal. Selain itu dengan komunikasi matematika yang baik akan dapat menganalisis soal dan mengikuti langkah-langkah penyelesaian sesuai rumus. Sayangnya kemampuan menganalisis ini masih kurang, mahasiswa lebih banyak yang menjawab langsung pertanyaan tanpa menganalisis terlebih dahulu, inilah yang menyebabkan kemampuan komunikasi matematika mahasiswa masih rendah. Hal ini senada dengan pendapat Nofrianto, dkk (2017) yang menyatakan bahwa kemampuan dalam memahami simbol dan menggunakannya dalam pemecahan masalah belum begitu memuaskan. Rendahnya kemampuan komunikasi matematika ini ditunjukkan oleh analisis hasil kerja.
Penelitian ini dilakukan pada mahasiswa semester 6 dengan mata kuliah metode numerik. Mata kuliah ini termasuk mata kuliah yang membutuhkan analisis. Mahasiswa dituntut untuk mampu menyelesaikan persoalan matematika sesuai tahapan yang diberikan, karena itu mahasiswa dengan kemampuan komunikasi matematika yang baik akan dapat menyelesaikan soal metode numerik lebih mudah.

Gambar 1 menunjukan salah satu contoh hasil pengerjaan soal yang dikerjakan mahasiswa dengan kemampuan komunikasi matematika yang cukup baik. Dari gambar 1 terlihat bagaimana mahasiswa tersebut secara sistematis menyelesaikan soal metode numerik yang diminta kemudian menganalisis soal, menulis rumus yang diminta dan mengerjakan dengan tahapan-tahapan yang sesuai.

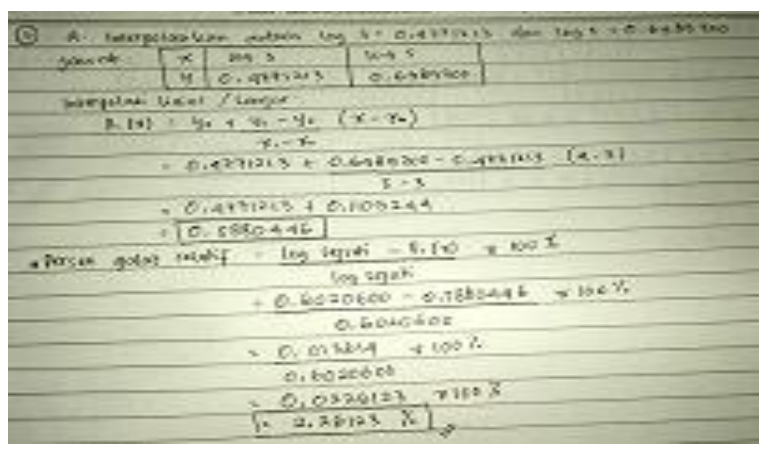

Gambar 1. Hasil penyelesaian soal metode numerik dari mahasiswa dengan kemampuan komunikasi cukup baik

Sayangnya tidak semua mahasiswa memiliki kemampuan komunikasi matematika yang sama. Ada beberapa mahasiswa termasuk ke dalam kelompok mahasiswa dengan kemampuan komunikasi matematika yang kurang baik. Gambar 2 menunjukkan salah satu contoh penyelesaian soal metode numerik oleh mahasiswa dengan kemampuan komunikasi matematika yang kurang baik. Dari gambar terlihat bahwa mahasiswa ini tidak mengerjakan secara sistematis dan bahkan tidak menuliskan rumus yang diminta, dan langsung menuliskan angka-angkanya. 


\section{JURNAL GANTANG. September 2018; III(2): 153 - 160 \\ p-ISSN. 2503-0671 \\ e-ISSN. 2548-5547}

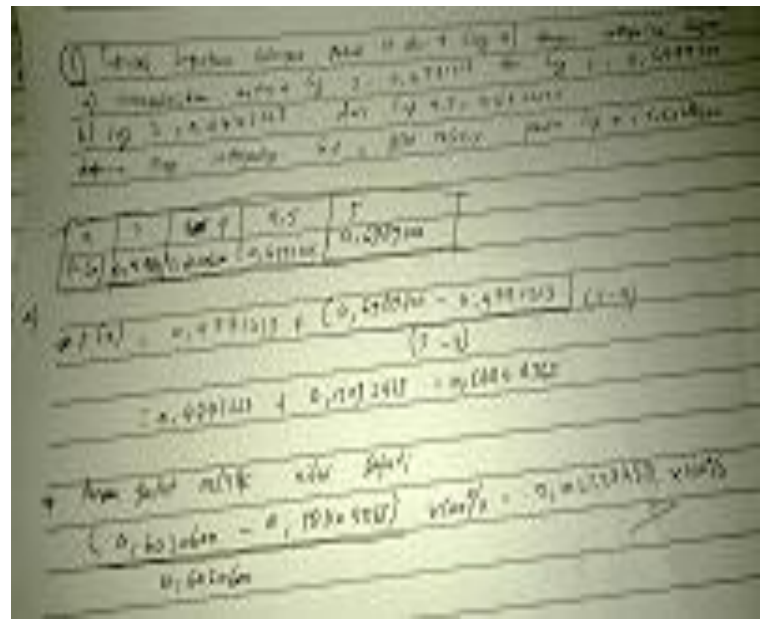

Gambar 2. Hasil penyelesaian soal metode numerik dari mahasiswa dengan kemampuan komunikasi kurang baik

Dari kedua gambar diatas dapat dibandingkan bagaimana perbedaan antara mahasiswa dengan kemampuan komunikasi matematika yang baik dan yang kurang baik. Hal ini mungkin terjadi karena karakteristik setiap mahasiswa memang berbeda.

Dalam satu kelas rata-rata terdapat 25-30 mahasiswa yang belajar. Pada kelas kontrol yang diterapkan dengan metode ekspositori tidak ada perbedaan yang diberikan kepada mahasiswa dengan kemampuan komunikasi matematika tinggi dan rendah. Setiap mahasiswa akan memperoleh perhatian dan perlakuan yang sama dalam pembelajaran mata kuliah metode numerik.

Berbeda halnya pada kelas eksperimen, pada kelas ini sebelum dilakukan pembelajaran mahasiswa akan dikelompokkan terlebih dahulu kedalam kelompok mahasiswa dengan kemampuan komunikasi yang berbeda yaitu tinggi, sedang dan rendah dengan cara diberikan soal pretest. Soal pretest yang diberikan adalah soal fungsi yang merupakan salah satu materi prasyarat mata kuliah metode numerik.

Gambar 3 menunjukkan contoh mahasiswa yang memiliki komunikasi matematika tinggi. Mahasiswa yang bisa menjawab dengan cara ini akan dikelompokkan ke dalam kelompok mahasiswa dengan kemampuan komunikasi tinggi.

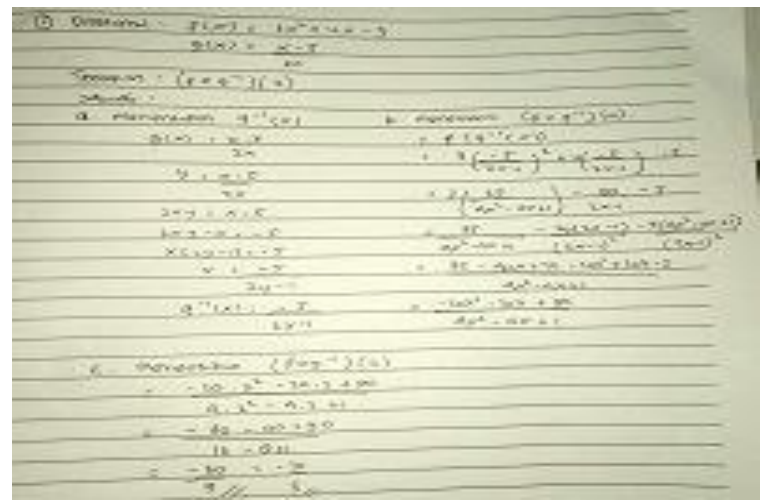

Gambar 3. Hasil penyelesaian soal fungsi dari mahasiswa dengan kemampuan komunikasi tinggi

Sedangkan mahasiswa yang termasuk kedalam kelompok dengan kemampuan komunikasi matematika sedang secara umum akan menjawab soal seperti pada gambar 4. Pada kelompok ini, jawaban yang diberikan benar hanya saja tidak sistematis. Mahasiswa cenderung mengerjakan soal dengan cara instan dikarenakan mahasiswa memiliki kemampuan komunikasi yang rendah.

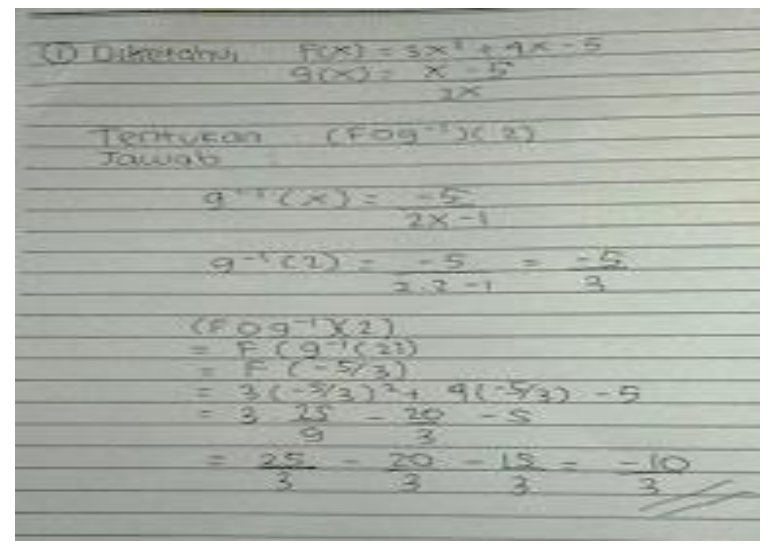

Gambar 4. Hasil penyelesaian soal fungsi dari mahasiswa dengan kemampuan komunikasi sedang

Terakhir adalah kelompok mahasiswa dengan kemampuan komunikasi rendah. Mahasiswa pada kelompok ini cenderung tidak dapat menyelesaikan soal yang diberikan dengan benar. Contoh penyelesaian soal pada kelompok ini dapat dilihat pada gambar 5. Pada gambar terlihat mahasiswa tidak mengetahui bagaimana cara menyelesaikan soal bahkan ia tidak memahami maksud dari soal ini, hal ini dikarenakan kemampuan komunikasi 
matematika masih tergolong rendah.

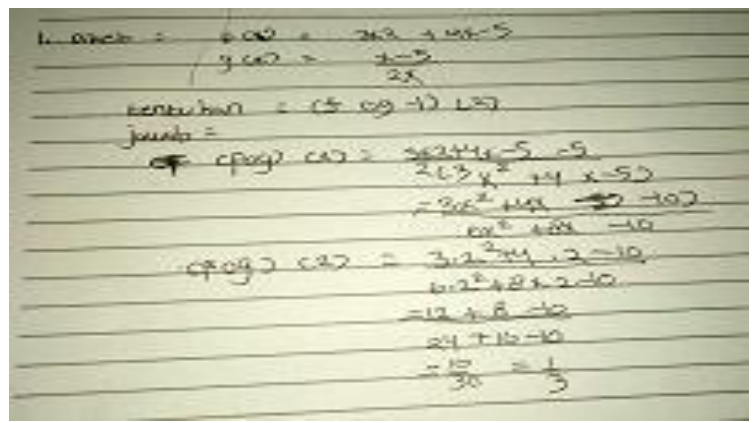

Gambar 5. Hasil penyelesaian soal fungsi dari mahasiswa dengan kemampuan komunikasi rendah

Setelah dibagi kelompok sesuai dengan perbedaan kemampuan komunikasi matematikanya, selanjutnya pembelajaran diberikan secara berbeda. Setiap kelompok tidak mendapat pembelajaran yang sama. Kelompok mahasiswa dengan kemampuan komunikasi rendah mendapat perhatian dan pembelajaran yang jauh lebih banyak dibandingkan kelompok lainnya. Hal ini membantu mahasiswa dengan komunikasi yang rendah lebih memahami pelajaran yang diberikan sehingga kemampuan komunikasi matematika lebih baik. Karena pada dasarnya model pembelajaran ATI menekankan pada pemberian perlakuan atau pembelajaran yang tepat sesuai dengan kemampuan masingmasing mahasiswa.

Senada dengan pendapat Erniati dkk (2014) menyatakan bahwa setiap siswa mempunyai kemampuan yang berbeda-beda. Ada yang memiliki kemampuan tinggi dan ada yang berkemampuan rendah atau pun sedang (Erniati, Wahyono, \& Nurjannah, 2014). Oleh karena itu, dalam rangka mengoptimalkan kemampuan komunikasi matematika dibutuhkan model pembelajaran yang dapat menyesuaikan pembelajaran dengan perbedaan kemampuan.

Untuk mencapai tujuannya, ATI berupaya menemukan dan memilih sejumlah strategi, pendekatan, metode/cara, kiat yang akan dijadikan sebagai perlakuan yang tepat, yaitu perlakuan yang sesuai dengan perbedaan kemampuan siswa (Nuraini et al., 2006). Dengan demikian, dapat disimpulkan bahwa tujuan utama model pembelajaran ATI adalah terciptanya optimalisasi/peningkatan prestasi belajar, melalui penyesuaian pembelajaran dengan perbedaan kemampuan siswa.

Hasil penelitian menyatakan bahwa terdapat perbedaan kemampuan komunikasi matematika mahasiswa yang diajar dengan model pembelajaran ATI dengan yang diajar model pembelajaran ekspositori. Pada tabel 1 menunjukkan bahwa nilai rata-rata dan nilai minimum kemampuan komunikasi matematika mahasiswa yang diajar model pembelajaran ATI lebih tinggi daripada yang diajar dengan model pembelajaran ekspositori. Hal ini menunjukkan bahwa penerapan model pembelajaran ATI mempengaruhi kemampuan komunikasi matematika.

Hal ini sesuai dengan pendapat Hermawan dkk (2014) yang menyatakan bahwa terdapat perbedaan hasil belajar antara peserta didik yang diajar dengan menggunakan model pembelajaran ATI dengan peserta didik yang diajar dengan menggunakan model pembelajaran konvensional (Hermawan, Eni, \& Erllina, 2014). Penggunaan model pembelajaran ATI memberikan pengaruh sebesar 38,3\% terhadap peningkatan hasil belajar peserta didik.

\section{Kesimpulan}

Berdasarkan data dan analisis data, pengujian hipotesis dilakukan dengan uji-t, diperoleh bahwa Ho ditolak yang berarti kemampuan komunikasi matematika mahasiswa di kelas yang menerapkan model pembelajaran ATI lebih baik dari kelas dengan model pembelajaran ekspositori. Sehingga dapat disimpulkan bahwa terdapat pengaruh model pembelajaran ATI terhadap kemampuan komunikasi matematika.

\section{Referensi}

Elida, N. (2012). Meningkatkan kemampuan komunikasi matematik siswa sekolah menengah pertama melalui pembelajaran Think-Talk-Write (TTW). Infinity, l(2), 178-185.

Erniati, Wahyono, U., \& Nurjannah. (2014). 
JURNAL GANTANG. September 2018; III(2): 153 - 160

p-ISSN. 2503-0671

e-ISSN. 2548-5547

Perbandingan hasil belajar fisika antara model pembelajaran Aptitude Treatment Interaction (ATI) dengan model pembelajaran Student Teams Achievment Division (STAD) pada siswa kelas X SMA Negeri 1 Ampana Kota. Jurnal Pendidikan Fisika Tadulako (JPFT), 2(1), 8-13.

Firdaus, S., \& Chyntia, E. (2016). Peningkatan kemampuan matematis siswa kelas VII-1 MTs Terpadu Al Maimun Kota Bekasi melalui penggunaan model pembelajaran kooperatif Think Pair Share (TPS). In Prosiding Seminar Nasional Pendidikan Matematika (pp. 37-44).

Hermawan, A., Eni, E., \& Erllina. (2014). Pengaruh model pembelajaran Aptitude Treatment Interaction (ATI) terhadap hasil belajar siswa materi struktur atom. Jurnal Pendidikan Dan Pembelajaran, $3(1), 1-11$.

Irawan, A., \& Febriyanti, C. (2016). Penerapan strategi pembelajaran kontekstual untuk meningkatkan kemampuan berpikir kritis matematika. Jurnal Ilmu Pendidikan, 22(1), 9-17.

Nofrianto, A., Maryuni, N., \& Amri, M. A. (2017). Komunikasi matematis siswa: pengaruh pendekatan matematika realistik. Jurnal Gantang, II(2), 113123.

Nuraini, O., Ainy, C., \& Suprapti, E. (2006). Penerapan model pembelajaran Aptitude Treatment Interaction (ATI) untuk meningkatkan hasil belajar siswa pada materi luas permukaan kubus dan balok kelas VIII SMP mardi putera Surabaya. Journal of Mathematics Education, Science and Technology, 2(3), 86-104.

Saregar, A., Diani, R., \& Kholid, R. (2017). Efektivitas penerapan model pembelajaran ATI (Aptitude Treatment Interaction) dan model pembelajaran TAI (Team Assisted Individualy): dampak terhadap hasil belajar fisika siswa. Jurnal Pendidikan Fisika Dan
Keilmuan (JPFK), 3(1), 28-35.

Syawal; Patahuddin; Alimuddin. (2017). The implementation of Aptitude Treatment Interaction (ATI) to improve learning motivation of low achievement students. Script Journal: Journal of Linguistic and English Teaching, 2(2), 224-236. https://doi.org/http://dx.doi.org/10.24903 /sj.v2i2.122 